\title{
SLAVIC AND KAZAKH FOLKLORE CALENDAR: TYPOLOGICAL AND ETHNO-CULTURAL PARALLELS
}

\author{
Galina Vlasova
}

\begin{abstract}
The study of multi-ethnic folk typology in the ethno-cultural region of Kazakhstan is of fundamental importance in the context of ethno-cultural typological parallels identifying the holiday calendar and rituals. The mechanism of folk typology is observed in ritual structures that compare the Slavic and Kazakh folklore calendars. There are typological parallels between all components in different Kazakhstan ethnic group celebrations: texts, rites, rituals, and cults.

The Kazakh and Slavic calendar systems have a collective character as functional and are passed down from generation to generation. The entire annual cycle of Eurasian festivals is based on the collective existence principle. The Slavic holiday calendar represents a dual faith synthesis of pagan and Christian entities while the Kazakh holiday calendar focuses on the connection of the pagan and Muslim principles.

Typologically, similar elements of Slavic and Kazakh holidays include structural relatedness, calendar confinement, similar archetypical rituals, and ceremonial models. Slavic and Kazakh ethnic and cultural contacts are reflected in the joint celebrations, in interethnic borrowing practices, rituals, games, and in Russian and Kazakh song performances by representatives of different ethnic groups. Field observations of Kazakh folklorists suggest the continuing existence of joint Nauryz and Shrovetide celebration traditions.

The folklore situation in Kazakhstan demonstrates both the different stages of closely related culture innovation of the Eastern Slavs and the typological relationship and bilateral borrowing through contact with unrelated Turkic ethnic groups.

The typological and ethno-cultural parallels as well as positive features of this holiday make it a universal phenomenon important for all members of a social or ethnic group.
\end{abstract}

Keywords: calendar, celebration, holidays, Kazakh, rituals, Russian

\section{INTRODUCTION}

The purpose of the article is to identify ethno-cultural and typological parallels between Eastern Slavic and Kazakh ritual folklore. The historical-genetic and historical and typological similarities of these two folk traditions are especially significant in the multilingual Kazakh environment. The historical and genetic 
comparison by Viktor Zhirmunsky (1979: 186) shows a "similarity between the phenomena as a result of their relationship to the origin and subsequent historically conditioned differences". Anikin (1996: 384) calls such similarity a "genetic typology", which means "the traditional folklore keeping the general original heritage of related peoples". The highlighted type of historical and genetic typology is clearly detected in the ritual structures of the East Slavic diaspora in Kazakhstan.

According to Zhirmunsky (1979: 186), historical and typological comparison "supporting the similarity of genetically unrelated phenomena by similar conditions of social development" is a leading method in comparative and historical folklore study. Historical and typological similarity, or "typological convergence" (Anikin's term), appears as a result of the creativity of independent nations and can be enhanced by contact occurring in Slavic and Turkic ethnic groups in Kazakhstan. Anikin (1996) particularly emphasises international relations and the folk-national elements of folk typology.

From my point of view the folklore situation in Kazakhstan demonstrates both the different stages of the closely related cultural innovation of the Eastern Slavs and the contact, typological relationship, and bilateral borrowing from unrelated Turkic ethnic groups.

\section{METHODS}

The current work is based on classical and contemporary recordings of Kazakh and Slavic folklore made during the twentieth century. The mechanism of folk typology is observed by the comparison of the ritual calendar structures of the Slavic and Kazakh folklore. The holiday calendars are different in their structural integrity, sacrality, and archetypal content, but both Kazakh and Russian calendars reveal openness, mobility, and worldly content. Cyclicality, the internal symmetry, and correlation with the seasons are typical of the holiday tradition of a single nation. It is evident that the different feasts of the ethnic groups include all the components of typological parallels: texts, rites, rituals, and cults.

Slavic holidays consist of two parts: a religious household and a folk rejoicing (carnivals, games, and feasts). The structure of Kazakh holidays includes similar elements: the assembly of all the members of the community to carry out festive ceremonies and a prayer reading, a festive meal, and a prohibition of labour. The main calendar and holy days are marked out in the Slavic calendar: spring/summer (Easter, Trinity Sunday, and Ivan Kupala (Feast of St. John the Baptist)), autumn (the Saviour and the Intercession), and winter 
(Christmastide and Shrovetide). The Kazakh holiday tradition consists of the spring festival (Nauryz - vernal equinox), the moving holidays (Ait ${ }^{1}$, Oraza ${ }^{2}$ Ait, and Kurban ${ }^{3}$ Ait), spring/summer holidays (Kymyz Muryndyk ${ }^{4}$, Seyil ${ }^{5}$, and Shokran ${ }^{6}$ ) and the autumn holiday (Sabantuy ${ }^{7}$.

The collective principle dominates in traditional rituals and festive complexes, and is reflected in collective creation and reproduction and in the performance of rites and texts. Thus the arrangement of family-related meetings and the invitation of guests, meeting with neighbours, and festive meals at New Year, Shrovetide (New Advent), Nauryz (Turkic-Islamic New Year) and Ait (remembering of ancestors) are obligatory. A characteristic feature of Slavic festive culture is the involvement of all the participants in the ritual action and non-discrimination against spectators and participants according to the principal of 'celebration of all for all'. An important feature of Kazakh holidays is their mass character and the inclusion of all the holiday action members, regardless of sex, age, or social status. Community and commune are the most significant elements of any festival. The entire annual cycle of Eurasian folk festivals is based on the principle of collective existence: collectively going from door to door singing congratulatory songs (Christmas carols or koliadok and Zharapazans ${ }^{8}$ ), mass celebrations and family visits on the great calendar days and religious holidays.

The Kazakh and Slavic calendar systems have a collective and conciliar nature; they are handed down from generation to generation. But conciliarity is evident not only in the collective nature. The culture of festive games is not only a form of mass communication. It joins together an individual's ownership of the actualisation of the collective consciousness, collective memory, folklore, and mythological archetypes. Thus the Slavic holiday calendar represents a dual faith synthesis of pagan and Christian entities; Kazakh holidays are also focused on the connection of the pagan and Muslim principles. Ethnic Kazakh culture is formed by the Tengri faiths and beliefs. The religious basis of the ancient Turks was the worship of Heaven (Tengri) and Earth-Water (Umai). Orthodoxy and Islam bear the idea of unity. There "is a very important general point - the principle of conciliarism (umma - in the concepts of Islam) and the priority of the spiritual community of people in social interaction over their economic and class distinctions" are in their social doctrines (Ergaliev \& Tikhonova 1999: 63). 


\section{RESULTS}

The ethno-cultural type specificity of the Slavic peoples is revealed through comparison of the moments of support of traditional calendar ceremonies. As for the annual cycle of Russian agricultural festivals, Propp (2000 [1963]) listed typologically recurring items: the ancestor cult, the vegetation cult, ritual food, merrymaking ritual, and death and laughter (fun ritual burial). Following this concept, repetitive and typological elements in celebrations of the two different ethnic groups, the Slavs and the Kazakhs, are distinguished.

\section{The Ancestor Cult}

There are many archaic features associated with the ancestor cult in Kazakh ceremony. "It is known, for example, that the nomadic cattle breeders addressed the spirits of the ancestors during Nauryz by making sacrifices and lighting lamps on the graves of the dead ancestors" (Mustafina 2001: 119).

The ancestor cult occupied a prominent place in Kazakh belief. In hard times Kazakhs call upon the names of their ancestors. Animal sacrifice and worship at their graves are arranged in their honour. Such events as the division of the clan into two independent clans, making peace between two warring clans, victory over an enemy, etc., marked Kazakh sacrifice to the ancestor spirits with a white mare or white stallion. ${ }^{9}$

An ancestor cult ritual prescribes prayers for the dead during Kurban Ait and performance of the Dead Remembrance during the Oraza Ait period.

Arriving at the summer site, Kazakhs offered sacrifices to the ancestral spirits and by reading a prayer from the Quran asked for happiness and wealth. Animal sacrifice is a long tradition among cattle breeders. It occupied an important place in Kazakh religious rites. (Kazakh 2002: 147)

Similar ancestor cults are observed in the Slavic culture. A 'meal' for deceased parents is arranged during the Christmastide and Shrovetide periods and the funeral rites connected with the commemoration of dead parents and relatives with ritual food are held during the Semik ${ }^{10}$ and Trinity Sunday periods. The ancestor cult is seen in the 'morgue games' and in giving presents to 'visitors from another world'. 


\section{The Vegetation Cult}

Many Slavic rites had ritual magic content and were associated with the vegetation cult. The vegetation cult of the Slavs is expressed in the worship of trees, flowers, and grass. The willow ceremonial, ${ }^{11}$ Trinity Sunday birch, ${ }^{12}$ the first and last sheaf, ${ }^{13}$ Ilya and Nicole 'beard tying' ceremonies ${ }^{14}$ were of great importance for agrarian people. Slavic pagan and Christian gods help and patronise farmers; Shrovetide, Kostroma ${ }^{15}$, Spring, Ilya, Egoriy, Christ, and the Virgin Mary are the main participants and heroes of calendar rituals and songs. The Kazakh names of agrarian prayer deities are Dihan Baba and Kydyr. The Slavic Ilya watching the fields and the holy Kazakh Kydyr are farmers' assistants. "According to the widely popular belief, Kazakhs usually say that Kydyr helps farmers throw the first grain" (Mustafina 1992: 116). So "in the night of March 21-22 Kydyr visits his folk. His main feature is immortality. The name of Kydyr ('green') indicates a relationship with the plant world, so it is associated with Nauryz" (Kazakh 2002: 147). The name of Dihan Baba symbolises the beginning of the arable period. "Farmers glorified him and asked for rain. A social meal was organised in honour of Dihan Baba" (Kondybai 2005: 103).

The festive meal is one of the main features of any holiday. It is the part of a magical ritual that performs the function of increasing fertility. Ritual food is the integral component of the calendar, family, and religious cycles of Slavic and Kazakh holidays. The most important components of the Slavic dishes are grain and flour meal, cereal, pancakes, baked bread, kutya ${ }^{16}$, eggs, fish and meat dishes. All of these are prepared for Christmastide, Shrovetide, Easter, and Trinity Sunday. A traditional dish for Nauryz is Nauryz kozhe. "Nauryz kozhe is a ritual meal of seven components, representing seven vital principles: water, meat, salt, fat, flour, wheat, and milk. They symbolise happiness, success, wisdom, health, wealth, rapid growth, and the protection of the sky" (Mustafina 2001: 218). Ritual food is also prepared on zhailyau (summer pasture in the mountains) in summer, in the period of the first milking of mares - Kymyz Myryndyk (the First Mare). The winter is a period for sogum ${ }^{17}$. The same magic pervades the Slavic New Year and Shrovetide: a festive meal (roast pig and pancakes) should be hearty and greasy.

\section{The Cult of Fire and Water}

The cult of fire and water is realised in the rites of purification by washing, fumigation, and exorcism before the spring fieldwork and during Lent. The purgatorial power of fire was also described by Chokan Valikhanov: 
Fire has a cleansing quality. Purification was accomplished by passing between two fires. The purification rite is called Alasta among Kirghiz tribes. Leaving their winter sites, they walk, one by one, between two fires. The person giving the public oath must also be purified by fire. (Valikhanov 1984: 54)

Valikhanov highlights the magical character of the Kazakh cult of fire: one is not allowed to spit into the fire, one cannot pass through the fire, fire cures, acts as a patron for the home and as a sanctuary in the home.

The Slavs and Kazakhs attribute purgatorial, healing, and protective properties to fire. They worship fire and the hearth. Oil, pancakes, and remnants of skoromnyi food ${ }^{18}$ are thrown into the fire. The Russians still practice pouring water on Ivan Kupala fires. The Kazakhs practice lighting Nauryz lamps and washing the whole body for the Kurban Ait. ${ }^{19}$

The Kazakhs believed in the purgatorial power of fire. Therefore, when leaving the winter sites, they stoked the fires and ran the cattle and the nomadic caravan between them to escape 'the evil spirits' when moving to their summer sites. The summer sites were also fumigated with fire and smoked to drive away the evil spirits. (Mustafina 2001: 34)

During Lent and Oraza purgatorial rites are arranged. The Slavs fast, burn old clothes and shoes, sprinkle the house with holy water, and wash in the bath. The great fast during the month of Ramadan is mandatory for all healthy and ritually pure adult Muslims. Ritual purity, tahara, means both an external cleanliness and neatness and the release of all contamination. Bathing, cleaning, lighting a fire and lamps symbolically clean the soul and body of the believer. It should be noted that the purgatorial fire is a human cult, and that in different nations it is implemented in different specific rituals and ritual actions.

Passing from door to door and giving donations is an important element of festive ritual behaviour among the Slavs and Kazakhs. The main activities are carolling during the Christmastide period and Zharapazan singing ${ }^{20}$, visiting during Nauryz and Kurban Ait, treating children with food and money, giving alms at the end of the fast, gifts to wives and children during the Oraza Ait period, and aittyk (small gifts and souvenirs during Ait). The week after Christmastide the carol singers and volochebnicks (magicians) go around, congratulating the hosts and bearing gifts for them. During the winter and spring/summer, Kazakh gifting and feast rituals are of great significance. "Every year during the big lent (Oraza) people go to the mosque, present a donation in memory of the dead and read the Quran" (Religion). Pitir is not only a religious concept, but also the worship of the dead and a tribute in respect to them. Orphans, widows, and other needy people receive sadaqa $h^{21}$. The person receiving sadaqa $h$ 
expresses good wishes for the family and relatives of the donator. Donating is the duty of every man. ${ }^{22}$

\section{Games and Festivals}

Games, entertainment, and dressing up structurally organise the holiday complex of the ethnic nations of Eurasia. There is dressing up at Christmastide and numerous pancake games for the Slavs. For Kazakhs there are performances, the games of badik and baksy ${ }^{23}$, and the mass celebrations of Nauryz and Sabantuy. Like elsewhere in Middle Asia and Europe, festive laughter is associated with fertility and magic. The role of laughter in Slavic and Kazakh calendar ceremonies is related to the renewal of nature festivals. Thus in the rituals of Nauryz the dual nature of the holiday is reflected: it combines birth and death, joy and sorrow. Fun on Pancake Day is universal. The emphasis during the carnival is on the equality of classes and age groups; the mutual exchange of gifts is also typical of many Slavic and Kazakh rituals.

\section{Dual Faith}

As previously mentioned, dual faith is the distinctive feature of Slavic and Kazakh festive culture. It is realised in domestic Orthodoxy and everyday Islam. The cult of the saints is at the heart of the Slavic folk calendar: George (the protector of cattle), Ilya (patron of the harvest and fertility), the Virgin Mary (the heavenly intercessor and patron of women in childbirth), Nicola, Kuzma and Damian (helpers and protectors against evil).

Many Christian saints replaced the pagan gods in the national consciousness, accepting their roles and taking their place in the pantheon. According to the pagan scheme every holy person was responsible for a certain sphere of nature or human activity. The saints were asked to help on all occasions with a prayer. Vows were made to them, sacrifices and gifts were offered. Simultaneously, people were offended when the saints did not fulfil requests and therefore punished the saints. (Tolstaia 1995: 151)

Festive forms and manifestations of folk Islam are varied in Kazakh culture. According to Mustafina (2001: 33), the Muslim cult of the saints was formed under the influence of archaic ideas treasuring the notion of numerous Gods. There were the saints associated with the cult of pre-Islamic nature. Kazakhs, among others, worshiped wells and mountains, honoured spirits of the trees 
(Julie-Bastau, Kazy-kyrt, Zhylaghan-Ata, and others), the patron of agriculture Dihan Baba, and the patron of sheep Koshkar-ata.

The Kazakh people, like other ranching peoples, preserved customs and beliefs connected with cattle, which for centuries have been transmitted from generation to generation. Thus, the patron saint of horses is Kambar or Zhylkyshi-ata, the sheep patron is Shopan-ata, the camel patron is Oysylkarda, the cattle patron is Zengi Baba and for goats Seksek (Shekshek) ata. The patron of agriculture and farmers in Kazakhstan is Dihan Baba. The giver of all possible blessings and abundance is the prophet Kydyr. (ibid.: 31)

Using historical and cultural typology (structural analysis) as the most universal method of research in comparing ethnic and cultural traditions of various cultures and studying their interaction, the researchers focus on the dominant motifs and images used to measure the cultural contacts and typological loans. By using such methods we are able to typologically separate the ceremonial ritual and textual and image motifs of Slavic and Kazakh holidays.

The New Year is celebrated by Kazakhs in spring, marking the beginning of a new working cycle. With the introduction of the Muslim calendar, it was timed to March 22 - the day of the vernal equinox. This was exactly in the period of Slavic Shrovetide, coinciding with the celebration of the March New Year. "Of particular importance was the celebration of the New Year, called Ulystyn Uly kyni in ancient times (the most important day of society) and later renamed Nauryz" (Kaskabasov 2000: 151).

As compared to the Slavic Shrovetide, the typologically similar ceremonies at Nauryz are masking, making female effigies, the playful nature of the holiday, and the ritual meal. On this day in every home the luxurious festive menu or dostarkhan consists of seven dishes and the traditional cooking is Nauryz kozhe. The host of the house tries to do everything to make his treats especially generous. The ritual holiday menu of Slavic winter and spring rituals features generous and abundant food. So, on Christmas Eve a rich festive meal vechora is prepared, part of which is always koliva - porridge made of wheat or rice and raisins. One of the seven components of Nauryz kozhe is wheat.

The most significant similarity between Slavic and Kazakh holiday rites is purity. It is believed that when Nauryz, the patron of the year, enters a cleaned yurt where two lamps are lit near the place of honour, no sickness, failure, or adversity reach it. Chetvergova salt ${ }^{24}$, which is used for performing cleansing and has a protective function, is prepared for house cleaning and washing before Easter. As in Slavic ritual practices, the Kazakhs act to expel evil spirits. A general point is the cleansing power of fire. Two large fires are lit. Between 
them, following each other, in order of seniority, people go with torches lit from these fires. They go around the immediate vicinity, expelling evil spirits and all evil, reciting in chorus magic badikov spells in poetic form. ${ }^{25}$

Nauryz, like other holidays, is accompanied by national games, national wrestling, goat tearing, horse race (bayga) and spending time on altybakan ${ }^{26}$ swing.

On the first day of the New Year people staged festive games and had fun. The games, Ktyrauyk kamyr kempir (Pretended Old Merzlyachka) and Ak Borane (The White Snowstorm) simulated a battle between winter and summer. Winter was symbolically depicted as an old dough lady, departing (dying). (Kaskabasov 2000: 152)

Similar games resemble the effigy burning at Shrovetide, which symbolises the winter's farewell.

Kazakh folklorists' field observations suggest the continuing existence of a joint Nauryz and Shrovetide celebration tradition. According to informants from the Akmola region, the most joyous celebrations are held when Nauryz coincides with Shrovetide. There are examples of the existence of holiday complexes at the end of the twentieth and beginning of the twenty-first centuries:

The booths were built, trading was organised, and a straw effigy dressed as a woman was constructed and then burned. Pancakes and baursaks ${ }^{27}$ were baked. A decorated troika drove children. A high pole rubbed with soap was erected in the square and gifts were attached at the top. The one who managed to climb that pole could choose any gift. Nauryz is the Kazakh Shrovetide. (L. Pankratova, personal interview, Semenovka village, 2001)

Nauryz and Shrovetide celebrations are typical of the villages of the Zerenda and Balkash districts in the Akmola region. The performers point out that people treat such 'reconciliation' with approval:

We were cooking pancakes, baursaks and Nauryz kozhe. Altybakan swings were put up and the tie-ups were cut. The effigy was burned. All of this was done to drive away all the hardships and to greet the coming spring.

(G. Khlystun, personal interview, Sandyktau village, 2003)

As in all Islamic countries, two annual religious festivals are celebrated in Kazakhstan. They are Razgovenie, or the end of fasting, and the Oraza Ait (Easter Ait) and Kurban Ait 70 days later. Ait is a large international Islamic holiday. Oraza Ait begins 30 days after Oraza. This month is also called Ramadan. ${ }^{28}$ During the Ait period people wear clean clothes, congratulate each other by saying, "Kytty bolsyn!" (Happy day!), ask for aittyk or for forgiveness for their 
mistakes and offences. Those who die during Oraza Ait are considered good people.

The Easter and Trinity traditions of the Slavs have similar stereotypes: going to church, wishing friends and family well (hristosovaniye), commemorating the dead, visiting relatives, and observing the prohibition on working.

Another feature of Kazakh folklore ritual is the coincidence of working rites that is typical of Russian autumn rituals associated with the harvest. Such rituals are defined as industrial and domestic.

Rite groups and games have been associated with Kazakh cattle breeders' work. In summer, on Zhailyau, in the period of the first milking of the mares, Kymyz Myryndyk (The First Mare) ritual feast was arranged. It was accompanied by Seyil (entertainment) merriment with songs sung in honour of Zhylkyshy Ata, the patron saint of horses. The same entertainment and ritual feasts were held in the late summer and in the early autumn, when they stopped milking mares. (Kaskabasov 2000: 152)

Sabantuy (the festival in honour of spring sowing), the great holiday of Kazakh farmers, is celebrated during the harvest season. In the autumn the custom of cattle and horse slaughter and in the winter sogum are still carried out. The neighbours are welcome to help. It starts with baata söz (Kazakh traditional blessing reading) and then a treat is offered. According to the Russian tradition, this period in the autumn (from August 15 to November 14) is called Myasoed; it is the period when the church allows meat eating. During the Sabantuy period songs such as keusen (The Neighbour Share), al zhemi (Horse Food), and kyrman tasysyn (Let the Threshing Floor Be Plentiful) are sung. N. Turekulov believes that "Kazakh farming songs beginning with the words 'Sabantuy, Sabantuy! Slay sheep for the toy / Run bull, kop, kop! / the threshing floor is full of grain' are rarely heard today" (Turekulov 1982: 49). ${ }^{29}$

The herding and calendar songs are traditionally distinguished in Kazakh ritual song culture. The herding songs of Kazakh cattle breeders are considered genetically ancient, preserving magical and religious significance. In particular, the images of animal ancestors date back to the tört tylik, the ancient spirits.

The images of Kazakh pet ancestors are of the same type as Russian images, such as Christmas carols, Ovsenya, and Beautiful Spring. The positive songs, ensuring the good quality of animal welfare, are among the best of them. (Silchenko 1968: 129) 
For example:

The horns like the cauldron...

The brilliant horns...

The crispy joints...

Is that you, Zengi Baba. (ibid.)

Ideal images of birds and animals (horses, cows, camels, sheep, hawks, etc.), and ideal pastures with 'heavy grass' dominate in herders' songs. The idealised imagery of the Slavic agrarian carols resembles to some extent the imagery of herders' songs. Kazakh folklore researchers emphasise the utilitarian nature, sustainability of themes, and poetic images about the four types of cattle in the songs.

"Two kinds of ritual songs were associated with the Kazakh calendar: Nauryz and Zharapazan songs (Muslim fasting songs - uraza)" (ibid.: 130). These songs, like the Slavic spell songs and the songs of praise, are filled with archetypal content: their main motifs are reduced to the nature spell and the host praising. Obvious similarity is found in two genres of Kazakh and Russian ritual poetry: Nauryz and Zharapazan songs. The structure of the texts is of the same type: praising, good wishes, and gift claiming. People greet each other and wish wellbeing, based primarily on the ownership of livestock, especially its four main types, for example:

Welcome,

Let the New Year

Be successful for you.

We wish the New Year

Brings you all four

Types of livestock
Come out, people.

Watch the sheep-yard.

Oh, whose sheep are lambed,

Whose rams are born

Oh, the white-legged lambs,

Oh, the white-horned yearlings

Generous evening, good evening.

(N. Humeniuk, personal interview.)

In the comparative table a similar theme of 'cattle offspring' is shown, developed in the Nauryz song and the Slavic Carol of the Lord's cycle.

The similarity in genres was noted by M. Silchenko, who also emphasised the difference in the fact that the Nauryz songs contain didacticism. "They have plenty of direct didactic wishes, such as 'We wish you great happiness', 'Let four kinds of cattle multiply', and plenty of predictions" (Silchenko 1968: 125-152), for example: 
Ulys kuni qazan tolsa, Ol zhyly aq, mol bolar. Uly kisiden bata alsaq, Sonda olzhaly zhol bolar.
If the cauldron is full on the Great Day, There will be an abundance in the New Year. If you are blessed by the venerable old man, Successful will be your way.

Nauryz songs have structural and motif similarities with Zharapazan songs. The genre differences are the dual faith character and the religious content of Zharapazan songs. They are an appeal to the ancestor spirits (aruaham), to Allah, the prophets, and the saints. Zharapazan songs are reminiscent of Slavic New Year songs with their Christian content. The images of the saints and God are central in them. Let us compare the Kazakh Zharapazan and Russian New Year song texts:

The Lord will have mercy The saints will help. Happy is thy portion, Appointed by the Lord To constant existence.
The plough was working in the field.

And that plough was operated by the Lord.

The Virgin Mary was carrying cassocks ${ }^{30}$

And praying to the Lord:

The Lord give us wheat and

All the pashnitsa ${ }^{31}$.

I'm sowing

And wishing you a happy New Year!

(Performed by H. Bykova (b. 1910), Otradnoe village, Makinsky district.)

The singers (Zharapazanshi) improvised using traditional images and motifs wishing calves to cattle, health and welfare for the owners, gifts, etc.

Earlier in the winter and spring holidays the Zharapazan song improvisation was typical among the Kazakh youth. In the evening, the youth wandered from yard to yard with a song beginning with 'Zharapazan aitamys basyna fever' [We sing Zharapazan for one family and for another]. (Turekulov 1982: 57)

Turekulov also notes the similarities of the Kazakh Zharapazan and the Russian carols.

Mustafina (1992: 20) relates Zharapazan to current perceptions of songs from the mid-twentieth century and confirms that the older artists remember fragments of songs and improvisations of a laudatory nature that were sung by 7-15-year-old children, as well as adults, on the days of fasting at the windows of elderly fasting people. Forms and conditions of existence (a time for play, 
participation, donation) are of the same semantics of ritual behaviour as for the Russian carol singers and their Ukrainian counterpart - shchedrovalhschiki. Let us compare the texts:

\begin{tabular}{|l|l|}
\hline Zharapazan to sing, & Archival text: \\
I came to your home. & Schedrivochka schedrovala, \\
Let your cradle & Was looking into the little window. \\
Have two dzhigits ${ }^{32}$. & What have you, dear woman, cooked? \\
Anyone who comes to your door, & What have you baked? \\
Something should be handed & Bring it closer to the window, \\
down on a golden dish: & to the window, \\
Money seized in nuts & Be careful, do not break it. \\
Its shells to play with. & Dear people \\
(M. Babaeva, 50 years old). & Good evening, generous evening \\
& Be well. \\
& (Woman (b. 1934), Krasnoselskoe \\
& village.) \\
\hline
\end{tabular}

From the current comparison it is clear that Kazakh Zharapazan (Zharamazan), Slavic carols, and New Year songs are similar not only in existence, but in the structure and imagery of the text, including good wishes of wealth, health, children, livestock, and gifts: the Kazakhs ask for money, nuts, dostarhan ${ }^{33}$, and butter, and the Slavs ask for a ritual meal.

\section{CONCLUDING REMARKS}

Ethnic and cultural cooperation between Russians and Kazakhs was displayed especially in the spiritual life. Researchers believe that the tolerance aspect of Tengrianism allows the Kazakhs to adapt to an environment otherwise dominated by the traditions of non-Kazakh confessions. Ethno-cultural contacts in the spiritual culture are noted by the researchers in Christmastide and Shrovetide clothing in the late nineteenth and early twentieth centuries. Thus the Russian peasants and Cossacks wore Kazakh national costume and Russian girls wove coins into their braids. Turkic borrowings are also marked and were reflected in the Siberian Cossack martial arts and similar Kazakh wrestling kures ${ }^{34}$. During the Soviet period, when people of different nationalities participated in many festivals, battle with bags on a log gained popularity among the Russian population. On the other side, several Russian games were adopted into the Kazakh tradition of celebrating calendar holidays. 
Examples of supporting different stages of ethno-cultural parallels during the twentieth century include the following. Russian texts actively include Ukrainian and Kazakh words. Ukrainian, Russian, and Kazakh elements are marked in calendar holidays and wedding ceremonies, which were initially perceived as alien ethnic innovation (Nauryz and Shrovetide celebrations in one calendar period, common meal and Russian and Kazakh ritual food on religious and national holidays) and were subsequently transformed into an organic type of reformed holiday.

Since the late 1980s, there has been a growing interest in folk traditions. The activity of religious organisations has increased. The media as well as scientific and cultural institutions have more extensively spread knowledge of folklore, folk and Orthodox holidays. With new forms of entertainment, the media has naturally started to perform the functions that formerly used to be performed by games, holidays, and festivals. Scholars have ascertained some shifts in national mass culture. Television and other mass media in the Republic of Kazakhstan provide information about folk art, folklore, mythology (aitys ${ }^{35}$, ethnographic programmes). The attraction of the Kazakh youth to emulate and respect customs of their ancestors is also noted. In festive and ceremonial life the modern urban and rural religious festivals, old and new, as well as Russian, Ukrainian, and Kazakh folk customs successfully co-exist.

It should be noted that traditional ethnic festivals are updated and have become massive in Kazakhstan and Russia. Such holidays as Nauryz and Ait have really become national. This is due to the fact that the Kazakh ethnic group is in the process of a passionate rise, and representatives of ethnic groups show high levels of passionate tension, allowing them to actively participate in the revival of traditional culture and the formation of the modern ritual. The role of spectacular calendar public holidays in the sphere of leisure, and cultural and community life of the people is determined, as already noted, by the degree of their involvement in the sphere and specific relationships in which the old and the new show the degree of their adoption. In turn, the functioning of these factors depends on a number of historical and socio-cultural conditions. The most important of them are: the historical depth of the celebrations in people's lives, social and cultural characteristics of ethnic groups in the region, and the level and nature of urbanisation and migration processes in the folkloricethnographic region of Kazakhstan.

These parameters must be actualised by understanding popular culture as synodic integrity. The idea of conciliarism in the Eurasian holiday culture is reflected in the type of behavioural and collective consciousness, the relationship between the generations and ethnic groups in the dialogue of cultures. 
Typological and ethno-cultural parallels as well as the positive features of the holiday make it a universal phenomenon, which is important for all the members of a social or ethnic group.

\section{NOTES}

1 Ait is also used as a general word for Muslim celebrations.

${ }^{2}$ Oraza Ait is a three day ceremony that marks the end of the Great Lent Oraza. Oraza Ait is also called a 'small celebration' to be distinguished from the 'big celebration' or Kurban Ait.

${ }^{3}$ Kurban Ait is one of the most important Muslim feasts that takes place seventy days after the Great Lent Oraza. The ceremony is conducted according to the lunar calendar and therefore the beginning could shift approximately ten days. In early Arabic sources the celebration is also called 'the feast of sacrifice'.

4 The Holiday of the First Kumys (the time when mares could be milked again).

5 Collective celebration of holidays when the whole village walks in the street and sings celebratory songs.

6 Kazakh Thanksgiving.

7 The festival in honour of spring sowing.

8 Ritual songs of the Muslim fast.

9 See http://www.heritagenet.unesco.kz/kz/content/duhov_culture/religia/religia_in_kz.htm.

${ }^{10}$ Slavic commemorating of the dead.

${ }^{11}$ Verbnoe voskresenie or a week before the Great Lent celebrating the entering of Jesus to Jerusalem.

${ }^{12}$ A fertility ritual when a young birch is decorated and placed at home or in the fields.

13 The first and last sheaf of the harvest.

${ }^{14}$ Ritual finishing of the harvesting period.

${ }^{15}$ East Slavic fertility goddess.

${ }^{16}$ Ritual sweet grain pudding.

${ }^{17}$ Sogum is a process of preparing horse meat and beef for winter period. The meat is usually frozen or dried. Sogum is part of traditional Kazakh and other Turkic nomadic cultures.

${ }^{18}$ Special fat dishes that were not consumed during the fasting period. 
${ }^{19}$ Kurban Ait is one of the most important Muslim holidays, taking place after seventy days from the end of the Great Lent or Oraza.

${ }^{20}$ In this case certain ritual singing, performed during and after the Muslim Lent.

${ }^{21}$ Voluntary charity in Islam.

${ }^{22}$ See http://www.heritagenet.unesco.kz/kz/content/duhov_culture/religia/religia_in_kz.htm.

23 Traditional Kazakh games imitating the fight of warriors.

${ }^{24}$ Black salt prepared only once a year, on Maundy Thursday before Holy Easter; hence it is called Chetvergova (in Rus. chetverk - Thursday).

25 "A particular game associated with working life, which had ritual and magical character, was Bədik” ('Badik’) (Kaskabasov 2000: 152).

${ }^{26}$ Traditional Kazakh swing, used mainly by the youth during holidays.

${ }^{27}$ Traditional Kazakh scones, fried in oil.

${ }^{28}$ See http://www.heritagenet.unesco.kz/kz/content/duhov_culture/religia/religia_in_kz.htm.

${ }^{29}$ Kazakh folklore texts are cited in Russian (and translated into English) according to the definitive edition.

${ }^{30}$ The cassock, or soutane, is an item of Christian clerical clothing used by the clergy of Catholic, Eastern Orthodox, Anglican and Reformed churches.

31 Ploughed field.

${ }^{32}$ Skilful and brave equestrian.

${ }^{33}$ Dish made of different oriental sweetmeats.

${ }^{34}$ Kures is a form of wrestling widespread over the whole Central Asia, Southern Siberia, and Mongolia. Wrestles fight inside a circle drawn on the ground and the goal is to push the opponent out of the circle.

${ }^{35}$ Contest centred on improvised oral poetry spoken or sung to the accompaniment of traditional musical instruments.

\section{REFERENCES}

Anikin, Vladimir 1996. Teoriia fol'klora: Kurs lektsii. [Theory of Folklore: Course of Lectures.] Moskva: Moskovskii gosudarstvennyi universitet.

Ergaliev, Ilias \& Tikhonova, Tatiana 1999. Budushchee Kazakhstana v zerkale evraziistva. [The Future of Kazakhstan in the Mirror of Eurasianism.] Idei 
i real'nost' evraziistva. [Ideas and Reality of Eurasianism.]. Almaty: Daik-Press, pp. 60-66.

Kaskabasov, Seit 2000. Zolotaia zhila: istoki dukhovnoi kul'tury. [The Golden Vein: The Origins of Spiritual Culture.] Astana: Elorda.

Kazakh 2002 = Kazakhskie natsional'nye obychai i traditsii. [Kazakh National Traditions and Customs.] Almaty: Fond Soros - Kazakhstan.

Kondybai, Serikbol 2005. Kazakhskaia mifologiia: Kratkii slovar'. [Kazakh Mythology: Short Dictionary.] Almaty: Nurly Alem.

Mustafina, Raushan 1992. Predstavleniia, kul'ty, obriady u kazakhov v kontekste bytovogo islama v iuzhnom Kazakhstane v kontse XIX-XX vv. [Presentations, Cults, Kazakh Rituals in Everyday Islam in Southern Kazakhstan at the End of the 19th and in the 20th Centuries.] Alma-Ata: Kazak universiteti.

Mustafina, Raushan 2001. Bytovoi islam v Kazakhstane. [Everyday Islam in Kazakhstan.] In: M. Kozybaev (ed.) Obychai i obriady kazakhov v proshlom i nastoiashchem. [Customs and Rites of Kazakhs in the Past and Present.] Almaty: NITs Gylym, pp. 28-35.

Propp, Vladimir 2000 [1963]. Russkie agrarnye prazdniki: Opyt istoriko-etnograficheskogo issledovaniia. [Russian Agrarian Holidays: Experience of Historical and Ethnographic Research.] Moskva: Laburint.

Silchenko, Mikhail 1968. Obriadovo-bytovaia poeziia. [Ritual and Everyday Poetry.] In: Istoriia kazakhskoi literatury. T. 1. Kazakhskii fol'klor. Alma-Ata: Nauka, pp. 125-152.

Tolstaia, Svetlana 1995. Sviatye. [The Saints.] In: V. Petrukhin \& T. Agapkina \& L. Vinogradova \& S. Tolstaia (eds.) Slavianskaia mifologiia: entsiklopedicheskii slovar'. [Slavic Mythology: Encyclopaedic Dictionary.] Moskva: Ellis Lak, p. 416.

Turekulov, Nysanbek 1982. Sovremennyi kazakhskii fol'klor: Zhanrovo-strukturnyi analiz. [Modern Kazakh Folklore: Genre and Structural Analysis.] Alma-Ata: Mektep.

Valikhanov, Chokan 1984. Sledy shamanstva u kirgizov. [Traces of Shamanism among the Kirghiz.] In: Ch. Valikhanov. Sobranie sochinenii v piati tomakh. Tom 4. [Collected Works in Five Volumes. Vol. 4.] Alma-Ata: Glavnaia redaktsiia Kazakhskoi sovetskoi entsiklopedii, pp. 48-70. Available at https://yadi.sk/i/A1oj887DeqqZ8, last accessed on March 18, 2016.

Zhirmunsky 1979 = Zhirmunskii, Viktor. Sravnitel'no-istoricheskoe izuchenie fol'klora [Comparative Historical Study of Folklore.] In: V. Zhirmunskii. Sravnitel'noe literaturovedenie: Vostok i Zapad. [Comparative Literary Studies: East and West.] Leningrad: Nauka, pp. 185-191. 


\section{INTERNET SOURCES}

Religion $=$ Religiia $v$ Kazakhstane. [Religion in Kazakhstan.] Available at http://www. heritagenet.unesco.kz/kz/content/duhov_culture/religia/religia_in_kz.htm, last accessed on March 1, 2016.

\section{MANUSCRIPT SOURCES}

Fieldwork material from the years 2002-2006 in possession of the author. 